\title{
A STUDY ON BACTERIAL CONCRETE WITH SUGARCANE FIBERS FLEXURAL
} BEHAVIOR

\author{
MS. P. KALA ${ }^{1} \&$ DR. R. ANGELINE PRABHAVATHY ${ }^{2}$ \\ ${ }^{I}$ Research scholar, Department of Civil Engineering, Hindustan Institute of Technology and Science, Chennai, India. \\ ${ }^{2}$ Professor, Department of Civil Engineering, Hindustan Institute of Technology and Science, Chennai, India
}

\begin{abstract}
This work estimates the flexural behavior of conventional concrete (CC), bacterial concrete (BC), and bacterial concrete incorporated with sugarcane fibers (SBC) and spotlights the role of sugarcane fibers in the bacterial concrete. The bacteria used in this analysis was Bacillus subtitles in liquid form to an optimized value of $1 \%$ with a concentration of $10^{6}$. The sugarcane fibers with the grain size passing through a $4.75 \mathrm{~mm}$ sieve in replacement of fine aggregates with an optimized value of $0.1 \%$ were used. The beams which were cast using conventional, bacterial, and with sugarcane fibers concrete are total 36 numbers for 28, 56, 84, and 112 days respectively. In those beams, different stirrups spacing is adopted as $130 \mathrm{~mm}, 150 \mathrm{~mm}$, and $200 \mathrm{~mm}$. The concrete grade used for preparing concrete specimens was M25 and the beams were tested as per IS code 516 - 1999. The load at first crack, cracking behavior, cracking pattern, the pattern of deflections, and load at failure were observed and the values are tabulated. It is observed that the flexural behavior of bacterial concrete incorporated with sugarcane fibers was slightly improved compared to bacterial concrete and conventional concrete.

KEYWORDS: Stirrups, Bacillus Subtilis, Sugarcane fibers, Crack pattern, Deflections
\end{abstract}

Received: Dec 14, 2020; Accepted: Jan 04, 2021; Published: Jan 13, 2021; Paper Id.: IJMPERDFEB20212

\section{INTRODUCTION}

The beams are loading transferable members from slabs to columns which in turn are transferred to foundations. Crack formation in beams decides the longevity of the other structural members. It is necessary to check the loaddeflection characteristics of beams. These beams are categorized into three types. In a beam, the actual neutral axis is less than the critical neutral axis, then those beams are under reinforced beams and steel fails at first. When the actual neutral axis coincides with the critical neutral axis, then those beams are balanced sections and strain in steel and strain in concrete reaches maximum simultaneously. When the maximum strain in the concrete reaches first then those sections are over reinforced sections. The over reinforced sections are not provided to avoid brittle failure [1]. Flexural members are slender members that deform primarily by bending moments caused by concentrated couples or transverse forces. Flexural characterization is the most performed mechanical test on biocomposites after the tensile test. The flexural behavior of beams can be evaluated by conducting many tests [2]. The concrete with various types of fibers can improve the ductility, reduction in crack formation, and toughness.

Therefore, this study plans to compare the flexural behavior of $\mathrm{CC}, \mathrm{BC}$, and $\mathrm{SBC}$ beams that have almost the same compressive strength. The stirrups spacing's was kept as $130 \mathrm{~mm}, 150 \mathrm{~mm}$, and $200 \mathrm{~mm}$ spacing. The comparison of beams was done in terms of first crack load, maximum load, crack width, maximum deflection, 
crack patterns, stiffness, and ductility index and finally includes analytical methods [3].

\subsection{Materials used}

i) A Bacteria in liquid form and gram-positive type named Bacillus Subtilis which was purchased from the Microbiological Laboratory near Kaveripakkam in Tamil Nadu was used.

ii) A sugarcane fiber of grain size which is passing through a $4.75 \mathrm{~mm}$ sieve was used.

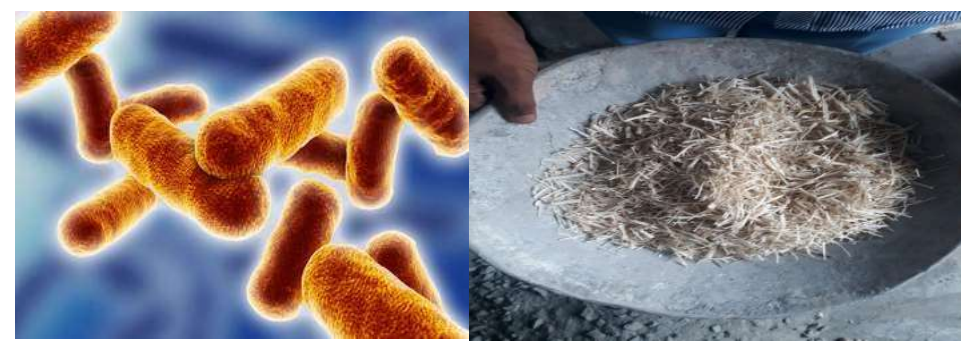

Figure 1: Bacteria and Sugarcane fibers

Materials proportions of conventional concrete (M25 grade), bacterial concrete, and Bacterial concrete incorporated with sugarcane fibers are:

Table 1: Mix proportions

\begin{tabular}{|l|l|l|l|}
\hline Component & CC & BC & SBC \\
\hline Cement & 1 & 1 & 1 \\
\hline Fine Aggregates & 1.67 & 1.67 & 1.66 \\
\hline Coarse Aggregates & 2.10 & 2.10 & 2.10 \\
\hline Water /cement Ratio & 0.44 & 0.44 & 0.44 \\
\hline $\begin{array}{l}\text { Bacterial Solution (\% of } \\
\text { water-cement ratio ) }\end{array}$ & - & 1 & 1 \\
\hline $\begin{array}{l}\text { Calcium Lactate (\% by } \\
\text { weight of cement) }\end{array}$ & - & 1 & 1 \\
\hline $\begin{array}{l}\text { Sugarcane Fibers (\% by } \\
\text { weight of fine aggregates ) }\end{array}$ & - & - & 0.1 \\
\hline
\end{tabular}

\section{EXPERIMENTAL INVESTIGATION}

\subsection{Preliminary Investigation}

In this stage, the percentage replacement of sugarcane fibers which passing through a $4.75 \mathrm{~mm}$ sieve was optimized. Investigations were made on cube specimens of $150 \mathrm{~mm}$ size with $0 \%, 0.5 \%$, and $0.1 \%$. The specimens were tested at 7 and 28 days. The Compressive strength with $0.1 \%$ of sugarcane fibers incorporated with bacterial concrete specimens was more than the compressive strength of other specimens.

The investigation was carried to study the flexural behavior of bacterial concrete incorporated with sugarcane fibers [4]. There were 12 beams of conventional concrete, 12 beams of bacterial concrete, and 12 beams of bacterial 
concrete with sugarcane fibers with a total count of 36 specimens. The beams were cast and tested at 28 days, 56 days, 84 days, and 112 days of curing. The beam size adopted for each beam was such that the failure would be due to flexure alone and the size was $150 \times 230 \times 1500 \mathrm{~mm}$. The details of the beams were tabulated in table 2 .

Table 2: Details of Conventional Concrete Specimens

\begin{tabular}{|c|c|c|}
\hline Sample ID & Size of the beam & Reinforcement Details \\
\hline \multicolumn{3}{|c|}{ For 130 mm Stirrups Spacing } \\
\hline $\begin{array}{l}\text { CC (for 28, } 56,84 \\
\text { and } 112 \text { days } \\
\text { curing) }\end{array}$ & $150 \mathrm{~mm} \times 230 \mathrm{~mm} \times 1500 \mathrm{~mm}$ & $\begin{array}{l}\text { Tension - } 3 \text { Nos of } 10 \mathrm{~mm} \text { dia } \\
\text { Nominal Compression bars }-2 \text { Nos of } 10 \mathrm{~mm} \\
\text { dia. } \\
\text { Shear Bars }-8 \mathrm{~mm} \text { dia } 2 \text { - legged stirrups }\end{array}$ \\
\hline \multicolumn{3}{|c|}{ For 150 mm Stirrups Spacing } \\
\hline $\begin{array}{l}\text { CC (for 28, } 56,84 \\
\text { and } 112 \text { days } \\
\text { curing) }\end{array}$ & $150 \mathrm{~mm} \times 230 \mathrm{~mm} \times 1500 \mathrm{~mm}$ & $\begin{array}{l}\text { Tension - } 3 \text { Nos of } 10 \mathrm{~mm} \text { dia } \\
\text { Nominal Compression bars }-2 \text { Nos of } 10 \mathrm{~mm} \\
\text { dia. } \\
\text { Shear Bars }-8 \mathrm{~mm} \text { dia } 2 \text { - legged stirrups }\end{array}$ \\
\hline \multicolumn{3}{|c|}{ For 200 mm Stirrups Spacing } \\
\hline $\begin{array}{l}\text { CC (for 28, } 56,84 \\
\text { and } 112 \text { days } \\
\text { curing) }\end{array}$ & $150 \mathrm{~mm} \times 230 \mathrm{~mm} \times 1500 \mathrm{~mm}$ & $\begin{array}{l}\text { Tension }-3 \text { Nos of } 10 \mathrm{~mm} \text { dia } \\
\text { Nominal Compression bars }-2 \text { Nos of } 10 \mathrm{~mm} \\
\text { dia. } \\
\text { Shear Bars }-8 \mathrm{~mm} \text { dia } 2 \text { - legged stirrups }\end{array}$ \\
\hline
\end{tabular}

Table 3: Details of Bacterial Concrete Specimens

\begin{tabular}{|c|c|c|}
\hline Sample ID & Size of the beam & Reinforcement Details \\
\hline \multicolumn{3}{|c|}{ For $130 \mathrm{~mm}$ Stirrups Spacing } \\
\hline $\begin{array}{lr}\text { BC (for } 28, & 56,84 \\
\text { and } 112 & \text { days } \\
\text { curing) }\end{array}$ & $150 \mathrm{~mm} \times 230 \mathrm{~mm} \times 1500 \mathrm{~mm}$ & $\begin{array}{l}\text { Tension }-3 \text { Nos of } 10 \mathrm{~mm} \text { dia } \\
\text { Nominal Compression bars }-2 \text { Nos of } 10 \mathrm{~mm} \\
\text { dia. } \\
\text { Shear Bars }-8 \mathrm{~mm} \text { dia } 2 \text { - legged stirrups }\end{array}$ \\
\hline \multicolumn{3}{|c|}{ For $150 \mathrm{~mm}$ Stirrups Spacing } \\
\hline $\begin{array}{lr}\text { BC (for } 28, & 56,84 \\
\text { and } 112 & \text { days } \\
\text { curing) }\end{array}$ & $150 \mathrm{~mm} \times 230 \mathrm{~mm} \times 1500 \mathrm{~mm}$ & $\begin{array}{l}\text { Tension }-3 \text { Nos of } 10 \mathrm{~mm} \text { dia } \\
\text { Nominal Compression bars }-2 \text { Nosof } 10 \mathrm{~mm} \text { dia. } \\
\text { Shear Bars }-8 \mathrm{~mm} \text { dia } 2 \text { - legged stirrups }\end{array}$ \\
\hline \multicolumn{3}{|c|}{ For 200 mm Stirrups Spacing } \\
\hline $\begin{array}{lr}\text { BC (for 28, } & 56,84 \\
\text { and } 112 & \text { days } \\
\text { curing) }\end{array}$ & $150 \mathrm{~mm} \times 230 \mathrm{~mm} \times 1500 \mathrm{~mm}$ & $\begin{array}{l}\text { Tension }-3 \text { Nos of } 10 \mathrm{~mm} \text { dia } \\
\text { Nominal Compression bars }-2 \text { Nos of } 10 \mathrm{~mm} \\
\text { dia. } \\
\text { Shear Bars }-8 \mathrm{~mm} \text { dia } 2 \text { - legged stirrups }\end{array}$ \\
\hline
\end{tabular}

Table 4: Details of Bacterial Concrete with Sugarcane fibers Specimens

\begin{tabular}{|c|c|c|}
\hline Sample ID & Size of the beam & Reinforcement Details \\
\hline \multicolumn{3}{|c|}{ For 130 mm Stirrups Spacing } \\
\hline $\begin{array}{l}\text { CC (for 28, } 56,84 \\
\text { and } 112 \text { days } \\
\text { curing) }\end{array}$ & $150 \mathrm{~mm} \times 230 \mathrm{~mm} \times 1500 \mathrm{~mm}$ & $\begin{array}{l}\text { Tension }-3 \text { Nos of } 10 \mathrm{~mm} \text { dia } \\
\text { Nominal Compression bars }-2 \text { Nos of } 10 \mathrm{~mm} \\
\text { dia. } \\
\text { Shear Bars }-8 \mathrm{~mm} \text { dia } 2 \text { - legged stirrups }\end{array}$ \\
\hline \multicolumn{3}{|c|}{ For 150 mm Stirrups Spacing } \\
\hline $\begin{array}{l}\text { CC } \text { (for 28, } 56,84 \\
\text { and } 112 \quad \text { days }\end{array}$ & $150 \mathrm{~mm} \times 230 \mathrm{~mm} \times 1500 \mathrm{~mm}$ & $\begin{array}{l}\text { Tension - } 3 \text { Nos of } 10 \mathrm{~mm} \text { dia } \\
\text { Nominal Compression bars }-2 \text { Nos of } 10 \mathrm{~mm}\end{array}$ \\
\hline
\end{tabular}




\begin{tabular}{|c|c|c|}
\hline curing) & & $\begin{array}{l}\text { dia. } \\
\text { Shear Bars }-8 \mathrm{~mm} \text { dia } 2 \text { - legged stirrups }\end{array}$ \\
\hline \multicolumn{3}{|c|}{ For 200 mm Stirrups Spacing } \\
\hline $\begin{array}{l}\text { CC (for 28, } 56,84 \\
\text { and } 112 \text { days } \\
\text { curing) }\end{array}$ & $150 \mathrm{~mm} \times 230 \mathrm{~mm} \times 1500 \mathrm{~mm}$ & $\begin{array}{l}\text { Tension }-3 \text { Nos of } 10 \mathrm{~mm} \text { dia } \\
\text { Nominal Compression bars }-2 \text { Nos of } 10 \mathrm{~mm} \\
\text { dia. } \\
\text { Shear Bars }-8 \mathrm{~mm} \text { dia } 2 \text { - legged stirrups }\end{array}$ \\
\hline
\end{tabular}

The experimental setups of beams are shown in fig.2 below. The beams were tested as per IS code $516-1999$ provisions with dial gauges having $0.001 \mathrm{~mm}$ least count for measuring the deflections at mid-span of the beam. The observations were recorded at different intervals until the failure of the beam. The behavior of the beam was observed at the first crack, at maximum deflection, and the descending portion of the load-deflection curve [5]. The crack pattern and its locations with their width were also perceived.

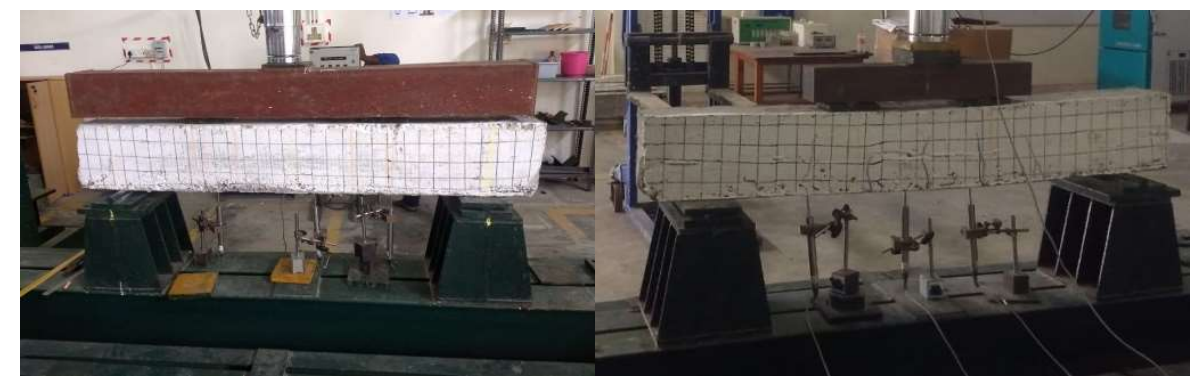

Figure 2: Experimental setup of beams

The crack development of conventional concrete beam, bacterial concrete beam, and bacterial concrete with sugarcane fibers during its loading are shown in fig.3-8 respectively. The cracks commenced at a load of $51.4 \mathrm{kN}$ for $\mathrm{CC}$, $49.3 \mathrm{kN}$ for $\mathrm{BC}$, and $61.9 \mathrm{kN}$ for $\mathrm{SBC}$ and the remaining values are shown in table 5, 6, and 7 respectively. The length of the cracks and the width of the cracks were recorded. The cracks had reached approximately half of the total depth of the beam from the bottom. The vertical cracks were also observed.
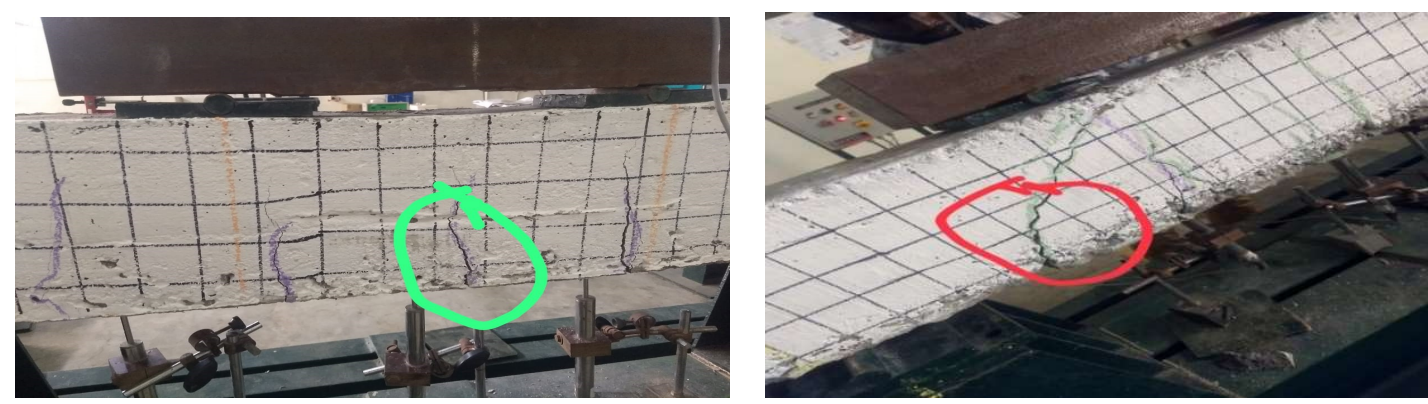

Figure 3: Crack Pattern of CC- (150) Fig.4 - Crack Pattern of CC - (200)

Table 5: Loading and Crack details of Specimens for $130 \mathrm{~mm}$ Stirrups Spacing

\begin{tabular}{|l|l|l|l|l|}
\hline $\begin{array}{c}\text { Age of } \\
\text { Concrete }\end{array}$ & \multicolumn{1}{|c|}{$\begin{array}{c}\text { Load at the first crack } \\
(\mathrm{KN})\end{array}$} & Max. Load(KN) & $\begin{array}{c}\text { Central Deflection } \\
\text { Max.Load } \\
(\mathbf{m m})\end{array}$ & $\begin{array}{c}\text { Maximum Crack } \\
\text { Width (mm) }\end{array}$ \\
\hline \multicolumn{5}{|c|}{ Conventional Concrete-CC -130 } \\
\hline 28 & 51.4 & 85.8 & 10.4 & 1.57 \\
\hline
\end{tabular}




\begin{tabular}{|c|c|c|c|c|}
\hline 56 & 52.2 & 86.9 & 10.1 & 1.51 \\
\hline 84 & 52.8 & 87.1 & 10.1 & 1.49 \\
\hline 112 & 53.2 & 88.7 & 9.7 & 1.47 \\
\hline \multicolumn{5}{|c|}{ Bacterial Concrete - BC- 130} \\
\hline 28 & 65.7 & 101.7 & 10.1 & 1.26 \\
\hline 56 & 66.2 & 103.1 & 9.8 & 1.21 \\
\hline 84 & 66.8 & 103.4 & 9.2 & 1.18 \\
\hline 112 & 67.8 & 104.8 & 9.0 & 1.15 \\
\hline \multicolumn{5}{|c|}{ Bacterial Concrete incorporated with Sugarcane Fibres- SBC-130 } \\
\hline 28 & 40.2 & 84.0 & 11.7 & 1.59 \\
\hline 56 & 42.5 & 86.1 & 11.2 & 1.55 \\
\hline 84 & 43.7 & 86.5 & 10.8 & 1.51 \\
\hline 112 & 44.3 & 87.9 & 10.2 & 1.49 \\
\hline
\end{tabular}

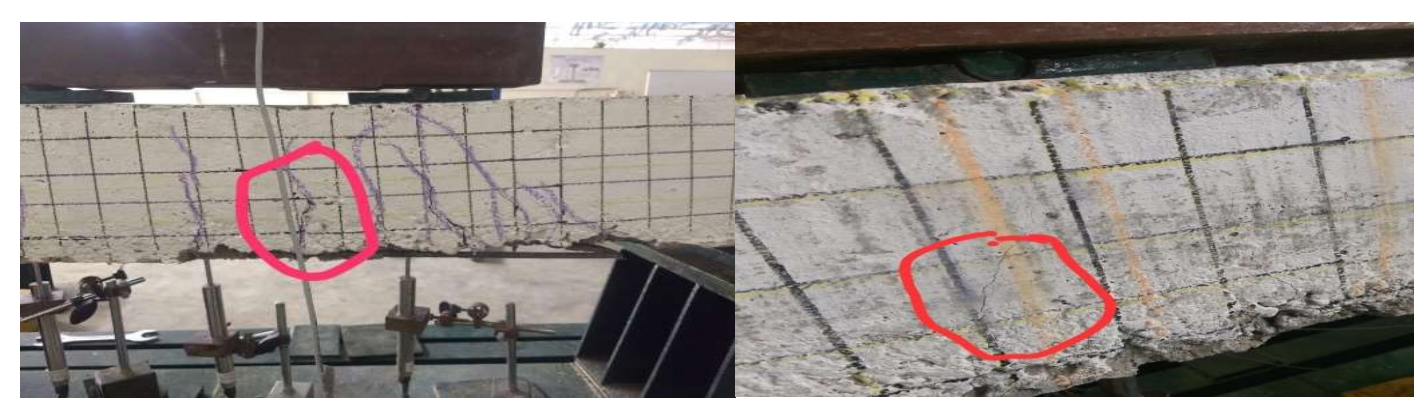

Figure 5: Crack Pattern of BC- (200) Fig.6 - Crack Pattern of BC- (200)

Table 6: Loading and Crack details of Specimens for $150 \mathrm{~mm}$ Stirrups Spacing

\begin{tabular}{|l|l|l|l|l|}
\hline $\begin{array}{l}\text { Age of } \\
\text { Concrete }\end{array}$ & $\begin{array}{l}\text { Load at the first crack } \\
(\mathbf{K N})\end{array}$ & Max. Load(KN) & $\begin{array}{l}\text { Central Deflection } \\
\text { @ Max.Load } \\
(\mathbf{m m})\end{array}$ & $\begin{array}{l}\text { Maximum Crack } \\
\text { Width (mm) }\end{array}$ \\
\hline Conventional Concrete-CC -150 & 49.3 & 82.8 & 10.7 & 1.62 \\
\hline 28 & 50.1 & 83.4 & 10.4 & 1.61 \\
\hline 56 & 50.4 & 85.9 & 10.2 & 1.57 \\
\hline 84 & 51.2 & 86.1 & 10.2 & 1.51 \\
\hline 112 & \multicolumn{5}{|l}{} \\
\hline Bacterial Concrete- BC- 150 & 100.5 & 10.7 & 1.30 \\
\hline 28 & 64.1 &
\end{tabular}




\begin{tabular}{|l|l|l|l|l|}
\hline 56 & 65.8 & 102.1 & 10.4 & 1.24 \\
\hline 84 & 66.2 & 102.8 & 10.2 & 1.20 \\
\hline 112 & 67.1 & 104.1 & 10.1 & 1.18 \\
\hline \multicolumn{6}{|l|}{ Bacterial Concrete incorporated with Sugarcane Fibres- SBC-150 } & 12.7 & 1.65 \\
\hline 28 & 40.2 & 84.2 & 12.4 & 1.62 \\
\hline 56 & 42.5 & 86.7 & 11.8 & 1.57 \\
\hline 84 & 43.7 & 88.2 & 11.6 & 1.48 \\
\hline 112 & 44.3 & 88.7 & & \\
\hline
\end{tabular}

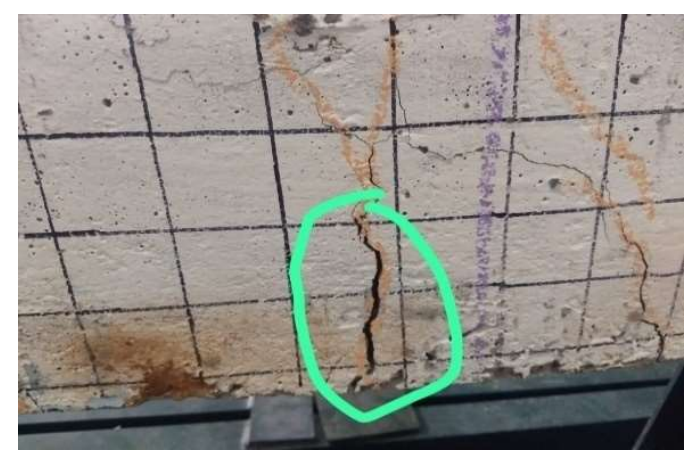

Figure 7: Crack Pattern of SBC- (150)

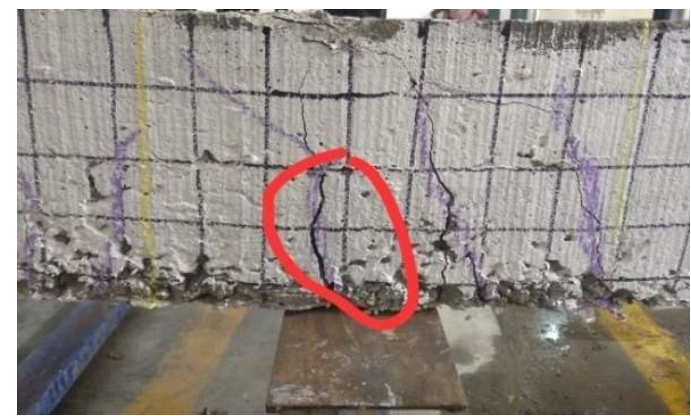

Figure 8: rack Pattern of SBC- (150)

Table 7: Loading and Crack details of Specimens for $200 \mathrm{~mm}$ Stirrups Spacing

\begin{tabular}{|l|l|l|l|l|}
\hline $\begin{array}{c}\text { Age of } \\
\text { Concrete }\end{array}$ & \multicolumn{1}{|c|}{$\begin{array}{c}\text { Load at the first crack } \\
(\mathrm{KN})\end{array}$} & Max. Load(KN) & $\begin{array}{c}\text { Central Deflection } \\
\text { a Max.Load } \\
(\mathbf{m m})\end{array}$ & $\begin{array}{c}\text { Maximum Crack } \\
\text { Width (mm) }\end{array}$ \\
\hline 28 & 61.9 & 99.2 & 6.8 & 1.50 \\
\hline 56 & 62.1 & 101.4 & 6.2 & 1.45 \\
\hline 84 & 62.7 & 102.3 & 6.0 & 1.39 \\
\hline
\end{tabular}




\begin{tabular}{|c|c|c|c|c|}
\hline 112 & 62.9 & 104.1 & 6.0 & 1.39 \\
\hline \multicolumn{5}{|c|}{ Bacterial Concrete - BC- 200} \\
\hline 28 & 27.3 & 144.3 & 12.9 & 1.25 \\
\hline 56 & 30.1 & 144.8 & 12.4 & 1.20 \\
\hline 84 & 32.4 & 145.1 & 11.9 & 1.15 \\
\hline 112 & 34.5 & 145.6 & 11.7 & 1.15 \\
\hline \multicolumn{5}{|c|}{ Bacterial Concrete incorporated with Sugarcane Fibres- SBC-200 } \\
\hline 28 & 24.1 & 86.7 & 12.6 & 1.30 \\
\hline 56 & 26.4 & 88.3 & 12.2 & 1.30 \\
\hline 84 & 28.6 & 91.2 & 12.0 & 1.21 \\
\hline 112 & 30.5 & 93.4 & 11.9 & 1.21 \\
\hline
\end{tabular}

\section{RESULTS AND DISCUSSIONS}

\subsection{General Findings}

Horizontal Cracks were not observed in any of the samples that meant no bond failure. The vertical cracks were found in the middle region of each sample and SBC samples with fewer numbers of vertical cracks.

\subsection{Behavior of Cracks}

First crack load for CC samples occurred at about 7 to $9 \%$ of the maximum load and for BC samples occurred at about 14 to $15 \%$ of the maximum load and for SBC samples at about 11 to $13 \%$ of the maximum load. The first crack has appeared in the mid-span of the CC beams and left one-third length of the beam in the samples of BC and SBC. All cracks were vertical and the crack reached more than half the depth of the beam in the case of SBC specimens [6].

\subsection{Width and spacing of Cracks}

The maximum width of the crack was $1.5 \mathrm{~mm}$ in the case of $\mathrm{CC}$ and $\mathrm{BC}$ specimens and $2.0 \mathrm{~mm}$ in $\mathrm{SBC}$ specimens. But the number of cracks was 7 to 8 in the case of CC beams and 5 to 6 in Bc and SBC beams.

\subsection{Deflection Behaviour}

The mid-span deflection was $10.8 \mathrm{~mm}$ in the $\mathrm{BC}$ samples. The deflection at the mid-span of $\mathrm{CC}$ beams was more than that of SBC beams [7].

\subsection{Flexural Strength}

The flexural strength of the SBC beams was decreased

Results for 28 days strength 


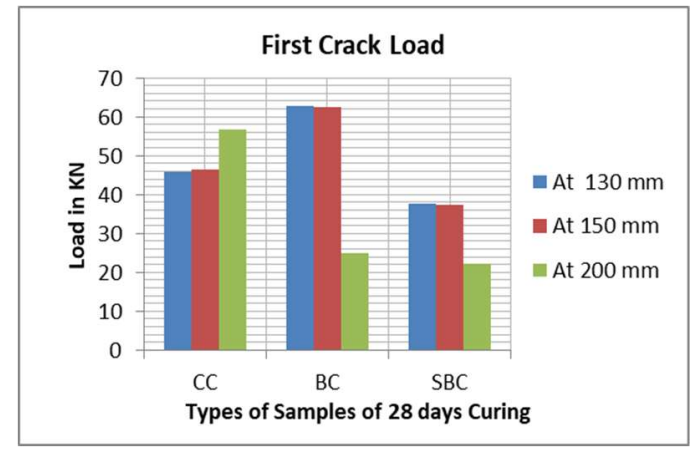

Figure 9: (a) First crack load Vs Different

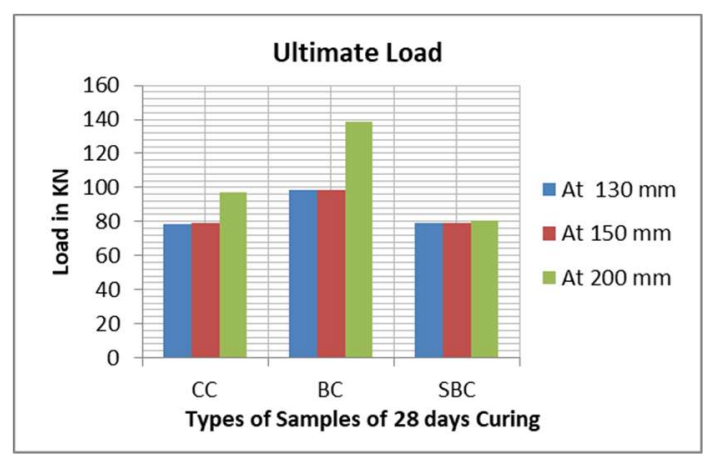

Figure 9: (b) Ultimate load Vs Different specimens

The maximum load versus load maximum deflection curves were drawn for the specimens at 28 days strength for the stirrups spacing $130 \mathrm{~mm}, 150 \mathrm{~mm}$ and 200mm and shown in fig.10 (a), (b), and (c). For the stirrups spacing 150mm, the strength and deflections of the beams were found almost nearer and for the other spacing's only BC specimens were found more strength [8].
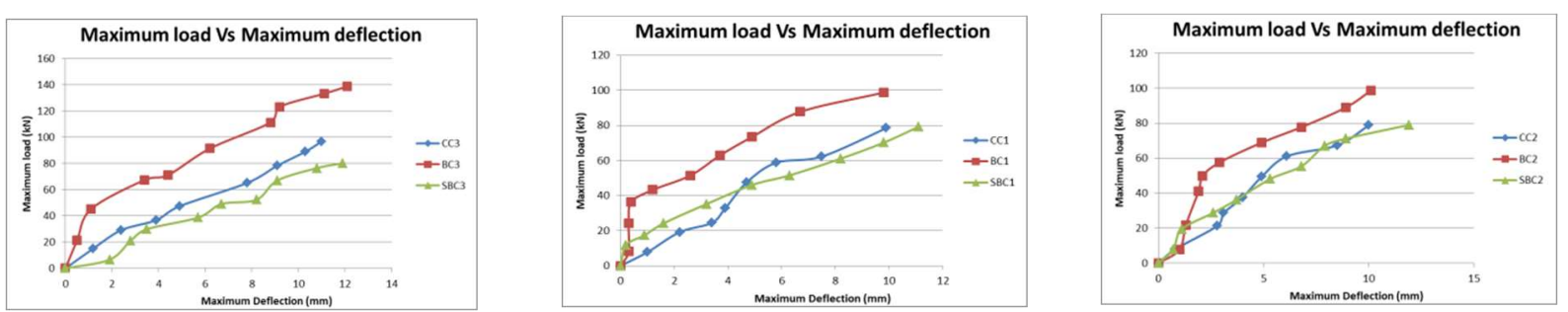

(a)

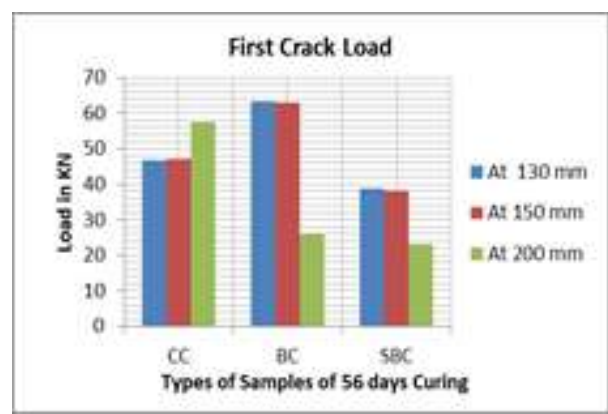




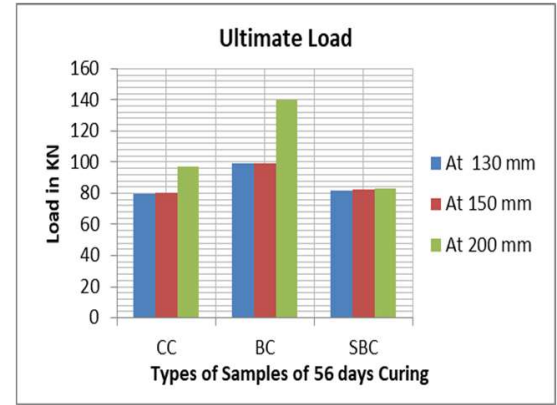

(b)
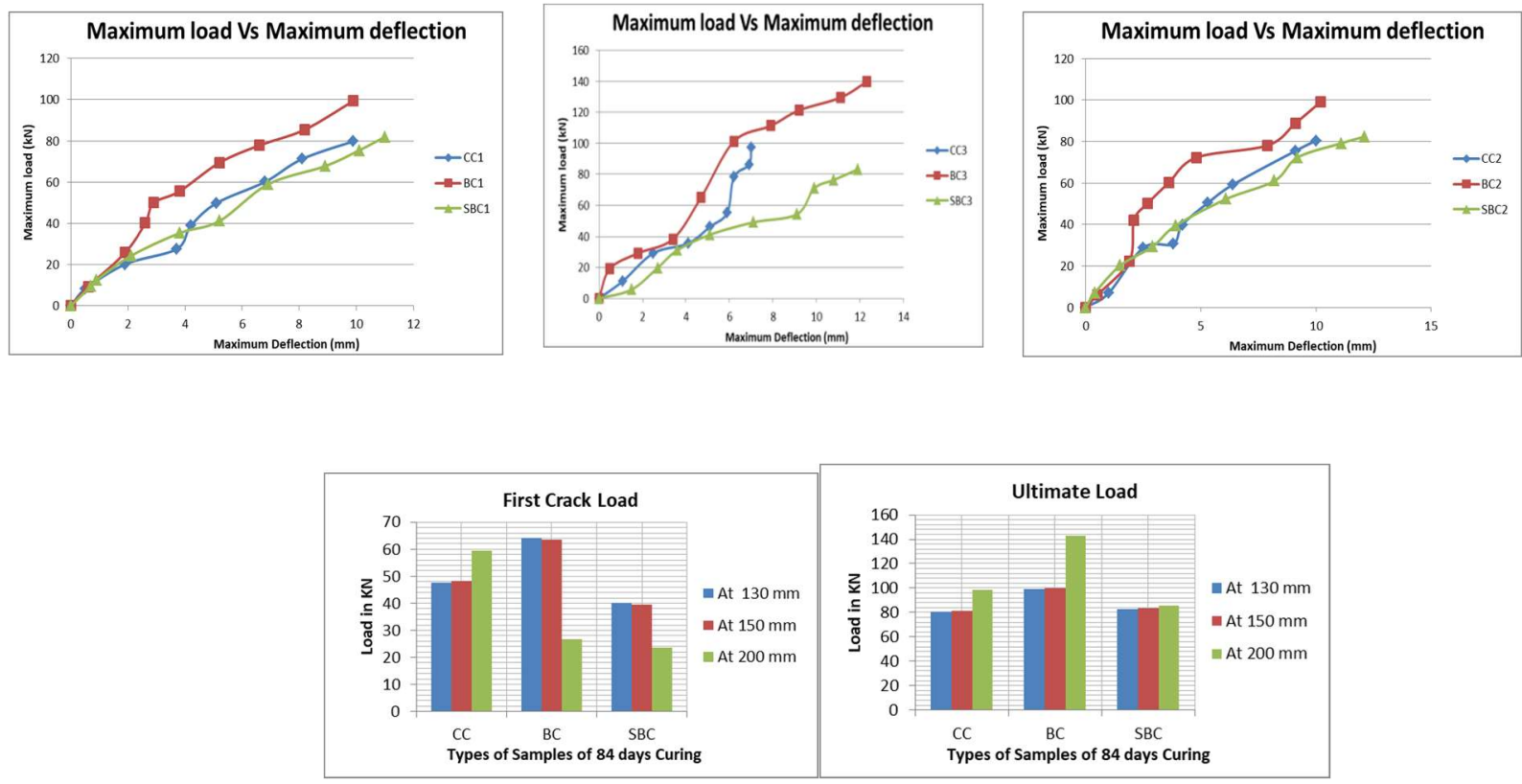

(c)

Figure 10: (a), (b) \& (c) Stiffness: load / deflection (84 days curing)

Post-Peak Stiffness The post-peak stiffness of the beams was found from the slope of the curves of the descending load side between the points of the cracking load. On the descending side of the curve, the nature of the beams was inelastic [9]. The stiffness of the specimens for the 28 days strength was represented in fig.11 (a), (b), and (c)

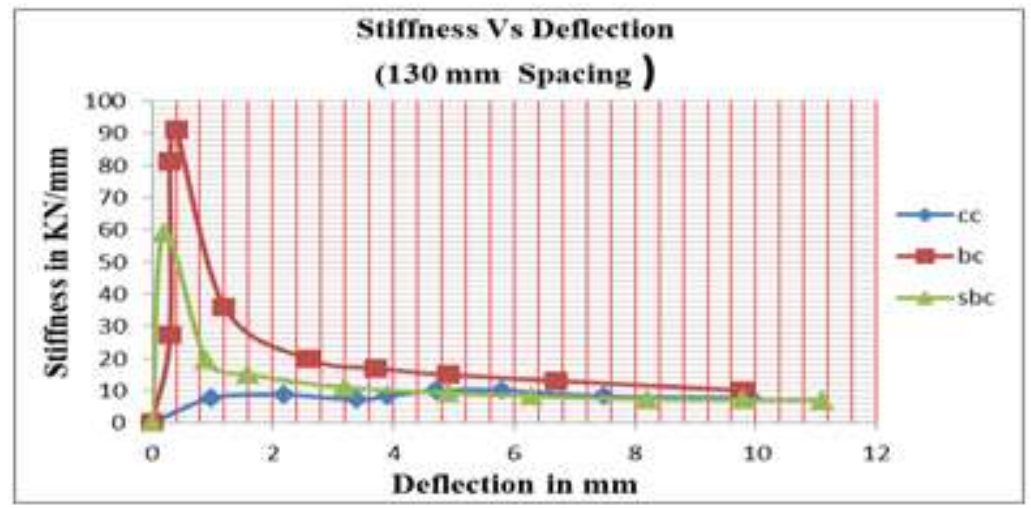

(a) 


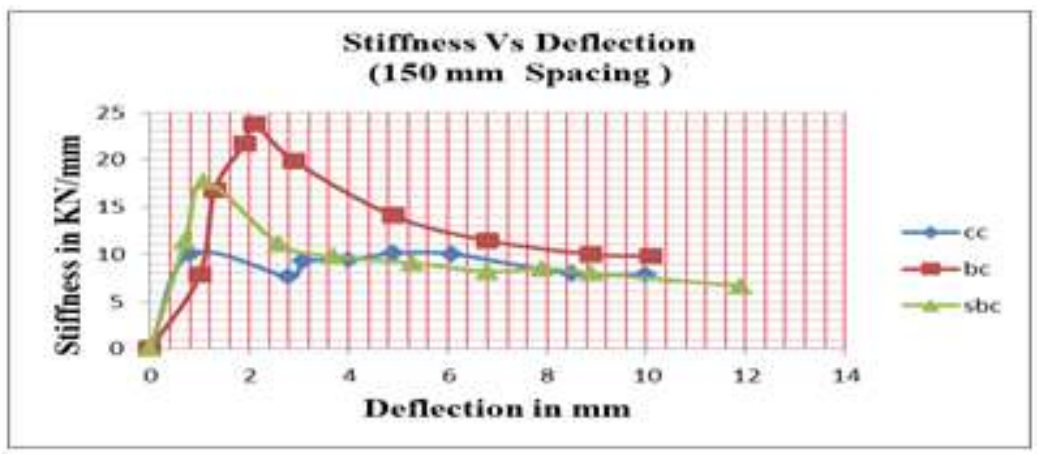

(b)

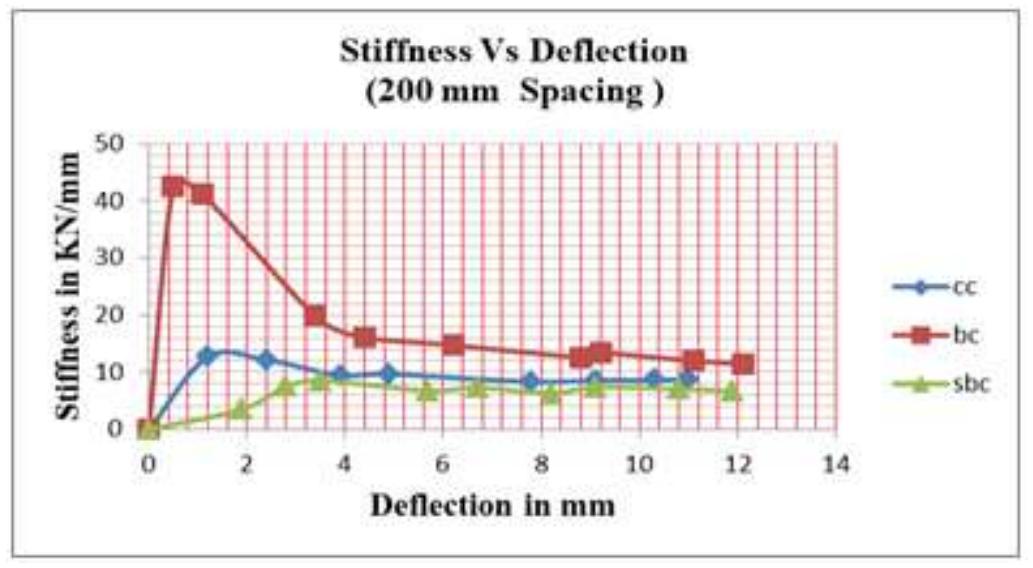

(c)

Figure 11: (a), (b) \& (c) The stiffness of the specimens for the 28 days strength

\subsection{Ductility}

The deflections at the midspan of each beam samples were measured to calculate the ductility index. The ductility of the beam was suggested by Tai-Kuang Lee et al. [10] by a formula given below,

$$
\mu=\Delta \mathrm{p} / \Delta \mathrm{y}
$$

where $\mu$ is the ductility index,

$\Delta \mathrm{p}$ is the deflection of the beam at the ultimate) load, and

$\Delta \mathrm{y}$ is the deflection of the beam at the yield load.

The values were tabulated in Table 8 the corresponding graph was represented in the figure. The indices of the $\mathrm{SBC}$ beams were decreased in comparison with the CC beams.

\section{RESULTS AND DISCUSSIONS}

\subsection{General Observations}

Vertical flexural cracks were observed in the constant-moment region and final failure occurred due to crushing of the compression concrete with a significant amount of ultimate deflection. When the maximum load was reached, the concrete cover on the compression zone started to fall for the beams with and without GGBS. Fig.3 shows the failure pattern of the 
test specimens. Crack formations were marked on the beam at every load-interval at the tension steel level. It was noticed that the first crack always appears close to the mid-span of the beam. The crack widths at service loads for GGBS concrete beams ranged between $0.16 \mathrm{~mm}$ to $0.2 \mathrm{~mm}$.

\subsection{Load-deflection Curve}

The experimental load-deflection curves of the RC beams with $0 \%$ and $40 \%$ GGBS when tested on the 28th day and 56th day are shown in Fig.4 and Fig.5 respectively. The average ultimate loads for controlled beams and 40\% GGBS concrete beams are $144 \mathrm{kN}$ and $135 \mathrm{kN}$ respectively at 28th day and it is $164 \mathrm{kN}$ and $178 \mathrm{kN}$ at 56th day. Though the ultimate loads for the Beams with $40 \%$ GGBS are less than that of the controlled beams on the 28th day, its ultimate load increases on the 56th day.

\subsection{Concrete and Steel Strain}

The concrete and steel strains measured at every load increments on the 28th day and 56th day are presented in Fig.6 and Fig.7. The positive strain value represents the tensile strain and the negative strain value indicates the compressive strain. Fig. 8 shows the comparison of concrete strain at the top surface and steel strain for all the beams at 28 and 56 days. These results revealed that GGBS concrete can achieve its full strain capacity under flexural loading.

\subsection{Flexural Toughness}

Flexural toughness is a measure of the resistance to bending and also the energy absorption capacity. This energy absorption capacity of each specimen was found from the area under the load- deflection curve. The flexural strength of a beam depends on the two factors such as concrete strength and reinforcement.

\section{FINITE ELEMENT ANALYSIS}

This study investigates experimentally and analytically the structural behavior of SBC concrete members and intends to verify the applicability of bacterial concrete incorporated with sugarcane fibers. To that goal, the behavior of reinforced concrete beams made of SBC concrete is evaluated experimentally in terms of flexure. Besides, the elastic modulus of SBC concrete for 25-MPa members obtained experimentally was used to perform the finite element analysis of the flexural members and the numerical results were compared with the experimental data.

Researchers can define their material models so that new materials could also be simulated in ABAQUS is a finite element package that has an extensive range of materials models such as elastomeric (rubber-like) and hyperelastic (soft tissue) material capabilities. So that had been used to create the models of the CC, BC and SBC tested specimens. In which, three separate stages were followed. The first stage was pre-processing, (creating the inputs) and the second was Processing (produce output file) and the third one was post processing (visual rendering stage). Using this software, the load-deflection variation along the length of the beam was assessed. The results from this analytical method were compared with the experimental results. In comparison the deflections of the theoretical values wireless than that of experimental values. 


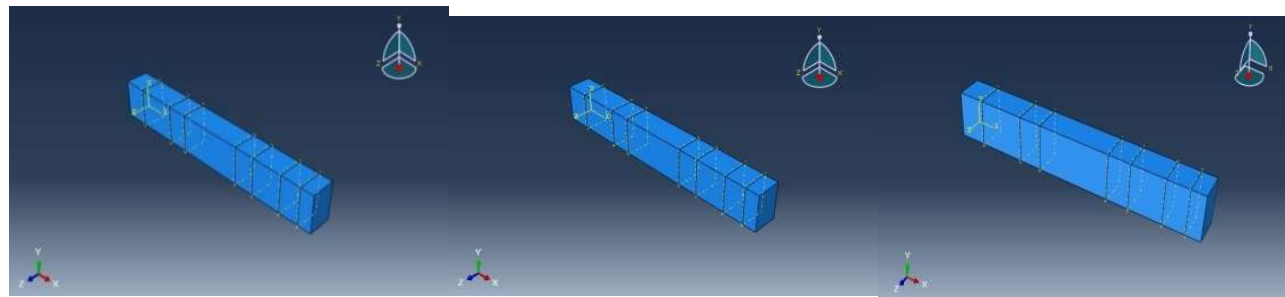

(a)

(b)

(c)

Figure12 (a), (b) \& (c) Samples of CC, BC and SBC Pre-Processing Stage

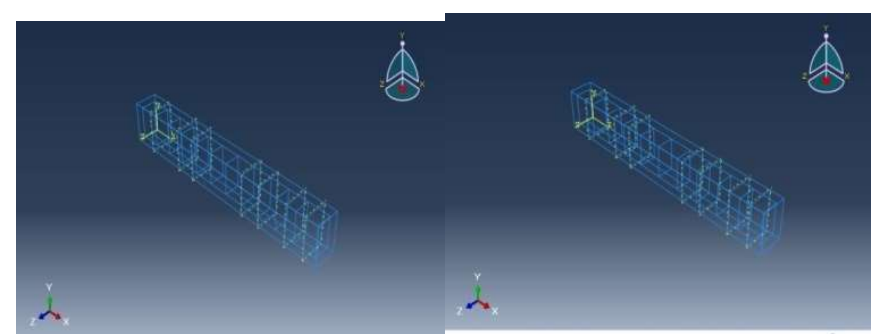

(a) (b)

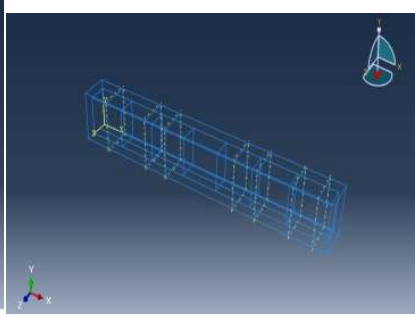

(c)

Figure13 (a), (b) \& (c) Samples of CC, BC and SBC Processing Stage

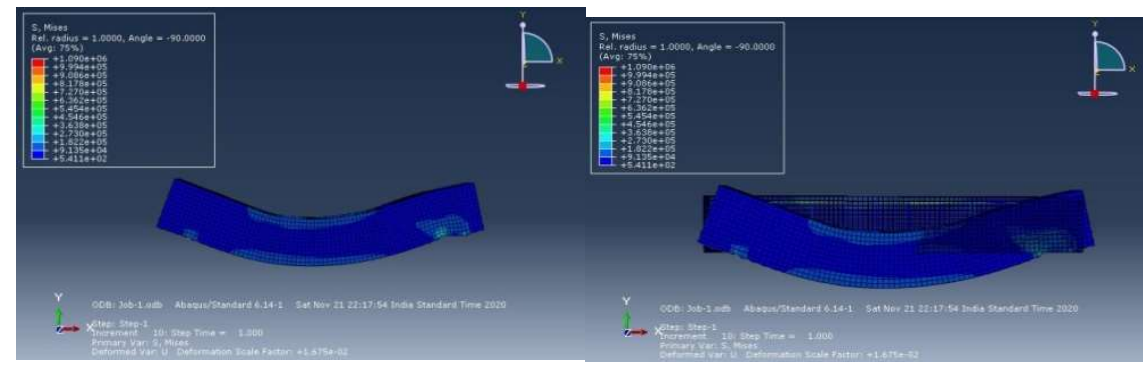

(a)

(b)

Figure 14 (a) \& (b) Deflections Curves Rendering Effect

The fig.12- 14 was shown the various processing stages of samples to analyze the behavior of the beams theoretically. In Tables 8 - 10, represent the theoretical and experimental values were tabulated and compare the deflections. It was obtain that the experimental values were more for the samples of $\mathrm{CC}, \mathrm{BC}$, and SBC.

Table 8: Comparison of Experimental and Analytical Deflection values of CC samples

\begin{tabular}{|l|l|l|l|l|l|l|}
\hline $\begin{array}{c}\text { Age of } \\
\text { concrete }\end{array}$ & \multicolumn{2}{|c|}{ CC -130 } & \multicolumn{2}{c|}{ BC -130 } & \multicolumn{2}{c|}{ SBC -130 } \\
\hline (days) & Exp & Ana & Exp & Ana & Exp & Ana \\
\hline 28 & 10.4 & 8.88 & 10.10 & 8.89 & 11.7 & 7.34 \\
\hline 56 & 10.1 & 7.68 & 9.80 & 9.01 & 11.2 & 7.60 \\
\hline 84 & 10.1 & 7.61 & 9.20 & 9.04 & 10.8 & 7.56 \\
\hline 112 & 9.7 & 7.60 & 9.00 & 9.09 & 10.2 & 7.68 \\
\hline
\end{tabular}


Table 9: Comparison of Experimental and Analytical Deflection values of BC samples

\begin{tabular}{|l|l|l|l|l|l|l|}
\hline $\begin{array}{c}\text { Age of } \\
\text { concrete }\end{array}$ & \multicolumn{2}{|c|}{ CC -150 } & \multicolumn{2}{c|}{ BC -150 } & \multicolumn{2}{c|}{ SBC -150 } \\
\hline (days) & Exp & Ana & Exp & Ana & Exp & Ana \\
\hline 28 & 10.7 & 7.23 & 10.7 & 8.77 & 12.7 & 7.35 \\
\hline 56 & 10.4 & 7.28 & 10.4 & 8.91 & 12.4 & 7.57 \\
\hline 84 & 10.2 & 7.5 & 10.2 & 8.98 & 11.8 & 7.70 \\
\hline 112 & 10.2 & 7.6 & 10.1 & 9.09 & 11.6 & 7.74 \\
\hline
\end{tabular}

Table 10: Comparison of Experimental and Analytical Deflection values of SBC samples

\begin{tabular}{|l|l|l|l|l|l|l|}
\hline $\begin{array}{c}\text { Age of } \\
\text { concrete }\end{array}$ & \multicolumn{2}{|c|}{ CC-200 } & \multicolumn{2}{c|}{ BC-200 } & \multicolumn{2}{c|}{ SBC-200 } \\
\hline (days) & Exp & Ana & Exp & Ana & Exp & Ana \\
\hline 28 & 9.22 & 8.67 & 12.9 & 12.62 & 12.6 & 7.58 \\
\hline 56 & 9.28 & 8.87 & 12.4 & 12.66 & 12.2 & 7.72 \\
\hline 84 & 9.5 & 8.95 & 11.9 & 12.69 & 12 & 7.97 \\
\hline 112 & 9.78 & 9.08 & 11.7 & 12.73 & 11.9 & 8.17 \\
\hline
\end{tabular}

\subsection{Experimental Results}

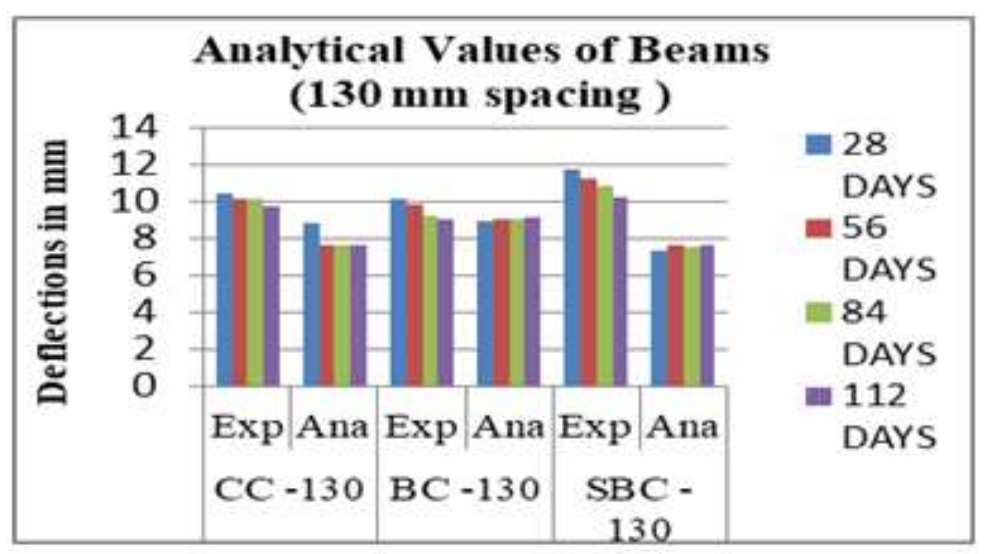



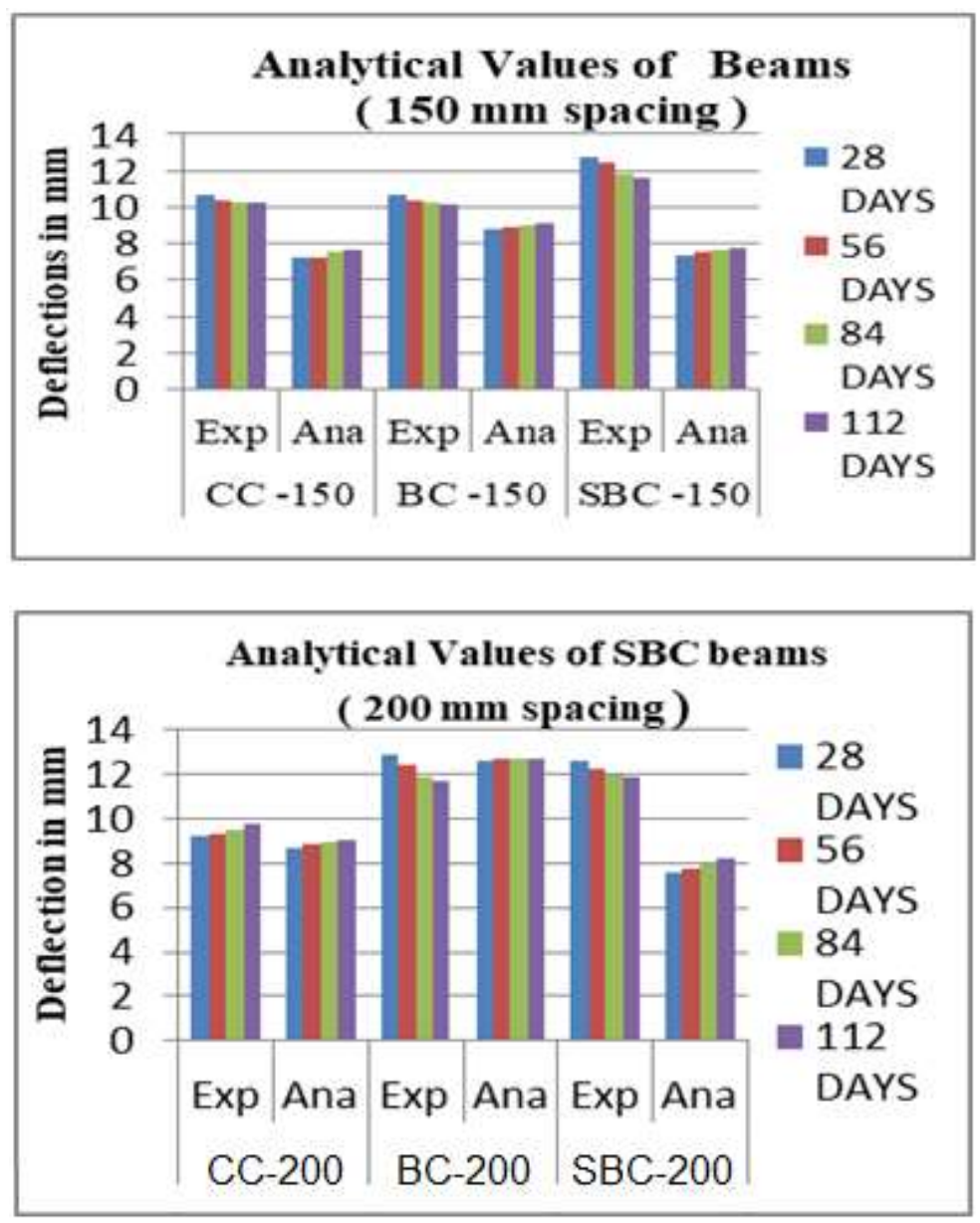

Figure 15: Experimental Results

\section{CONCLUSIONS}

- No shear cracks were found in SBC specimens.

- The numbers of cracks were less compared to $\mathrm{CC}$ and $\mathrm{BC}$ specimens.

- The deflections of the SBC specimens were less compared to CC and BC specimens.

- The failure of the specimens (SBC) was only due to flexure and not due to crushing.

- The crack width was within reasonable limits.

- The load-carrying capacity of the SBC beams was less compared to $\mathrm{CC}$ and $\mathrm{SBC}$ beams.

\section{REFERENCES}

1. Ali.A.Abbas, Sharifah M. Syed Mohsin, "Shear Behaviour of Steel-fiber-reinforced concrete simply supported beams", Institution of Civil Engineers, Structures and Buildings 167, Issue SB9, pages 544-558, September 2014.

2. ArunVigesh S, A sumathi, "Flexural behavior of RCC beams with externally bonded FRP", Earth and Environmental Series, 80, 012043, 2017.

3. AshrafAbdalkader et al, "Flexural Cracking Behaviour of Steel Fibre Reinforced Concrete Beams", International Journal of Scientific \& Technology Research ISSN: 2277-8616 Volume 6, Issue 08, August 2017. 
4. Deepthi K, Chaitanya Kumar J D, “Experimental Investigation of shear Behavior in Flexure Members", International Journal of Recent Technology and Engineering, Volume -7, Issue- 6C2, ISSN: 2277-3878, April 2019.

5. Kwang-Myong Lee, Sung Choi, "Flexural and Shear Behaviors of Reinforced Alkali-Activated Slag Concrete Beams", Advances in Materials Science and Engineering, volume, Article ID 5294290, 12 pages, 2017.

6. Naga Chaitanya $C$ et al, “An Experimental Study of Flexural Strength of Reinforced Concrete Beam Due To Corrosion”, IOSR Journal of Mechanical and Civil Engineering, e-ISSN: 2278-1684,p-ISSN: 2320-334X, Volume 11, Issue 4 Ver. II, PP 98-109, (Jul- Aug. 2014).

7. Rama Mohan Rao P, Karthik S, "Investigation on Flexural Behaviour of Beam with Bamboo as Main Rebars", International Journal of Recent Technology and Engineering, ISSN:2277-3878, Volume-7, Issue-4S2, December 2018.

8. S. K.Kulkarni, M.R Shiyekar, "Elastic properties of RCC under flexural loading-experimental and analytical approach", Indian Academy of Sciences, Volume 39, Part 3, pp.677-697, 2014.

9. ShathaAlasadi, PayamShafigh, "Experimental Study on the Flexural Behavior of over Reinforced Concrete Beams Bolted with Compression Steel Plate”, Part 1, Applied Science 2002, 10, 82223 January 2020.

10. Tai-Kuang Lee, Austin D.E. Pan, Estimating the relationship between tension reinforcement and ductility of reinforced concrete beam sections, Engineering Structures, Volume 25, Issue 8, 2003, Pages 1057-1067, ISSN 0141-0296, https://doi.org/10.1016/S0141-0296(03)00048-8. 

